\title{
NOTE
}

\section{REJECTING THE MINORITY DISCOUNT}

\section{INTRODUCTION}

At early common law, a holder of even a single share of a corporation's stock could veto any fundamental corporate change proposed by other shareholders. ${ }^{1}$ Unlike day-to-day business decisions, which fell within management's prerogatives, "fundamental" changes affected the very nature of a shareholder's investinent. In recognition of this effect, courts would allow shareholders to singlehandedly prevent such changes. ${ }^{2}$ This veto power preserved shareholders' expectations that the characteristics of their investments would remain unaltered even at the expense of economic efficiency and managerial authority.

The balance shifted, however, as corporate law recognized the importance of inaintaining a market for corporate control. Corporate regulation began to encourage business leaders to enter new fields, acquire other enterprises, and restructure mvestor rights. ${ }^{3}$ A sole dissenter's power to halt a merger or stop a substantial sale of assets drastically limited bnsiness leaders' ability to adapt to changing times. Thus, in order to encourage mergers, acquisitions, and other forms of corporate reorganization-all of which bring synergistic benefits to the business community and ultimately to the public at large-courts and legislatures eliminated the common law veto power. ${ }^{4}$

Minority shareholders are not, however, bound to accept such changes without recourse. In most cases, a dissenting shareholder will have an appraisal right, that is, a right to receive the "fair value" of her

1. 12B W. Fletcher, Cyclopedia of the Law of Private Corporations $\$ 5906.1$ (rev. perm. ed. 1984); see Voeller v. Neilston Warehouse Co., 311 U.S. 531, 535 n.6 (1941); Geddes v. Anaconda Copper Mining Co., 254 U.S. 590, 595-96 (1921).

2. Courts once considered the veto power to be of constitutional magnitude: each shareholder, they asserted, had a vested right to participate in the entity in which she originally invested. See Trustes of Dartmouth College v. Woodward, 17 U.S. (4 Wheat.) 518, 650 (1819); see also infra notes $19-20$ and accompanying text.

3. REVISED MODEL Business CORP. ACT ch. 13 introductory comment (1984); see also Woodward v. Quigley, 257 Iowa 1077, 1086-87, 133 N.W.2d 38, 42-43, modified on reh'g, 257 Iowa 1104, 136 N.W.2d 280 (1965).

4. See 1 F.H. O'NeAl \& R. Thompson, O'NeAI's OpPression of Minority SHareholdERS § 5.03, at 11-12 (2d ed. 1985). 
shares under a "dissenters' rights" statute. 5 This right to an appraisal, however, is normally a shareholder's exclusive remedy, ${ }^{6}$ unless she can convince a court to set aside a transaction as unlawful or fraudulent. ${ }^{7}$

Ideally, minority and majority shareholders will appraise minority shares on their own. ${ }^{8}$ Only when the parties cannot agree will courts step in to value shares. ${ }^{9}$ As the Revised Model Business Corporation Act stresses:

The objective of [the Act's dissenters' rights provision] is to permit each dissenter to receive fair value without the formality of judicial appraisal, which involves delays and uncertainties and legal expenses that are prohibitive to small investors. Appraisal is the ultimate sanc-

5. See infra notes 21-22 and accompanying text.

6. See, eg., REVISED MODEL BuSINESS CORP. ACT $\S 13.02(b)$. Twenty-six jurisdictions have specific statutory limitations on a dissenter's recourse to other remedies if appraisal is available. See REVISED MODEL BUSINESS CORP. ACT ANN. § 13.02 annot. (Supp. 1988) (listing twenty-five jurisdictions with such provisions as of Nov. 30, 1987); Miss. CODE ANN. § 79-4-13.02 (Supp. 1988) (similar provision effective Jan. 1, 1988). Even in the absence of a statutory provision, some courts hold that shareholders who complain only of unfaimess in a transaction have only the appraisal remedy. See, e.g., Weinberger v. UOP, Inc., 457 A.2d 701, 714-15 (Del. 1983). See generally Vorenberg, Exclusiveness of the Dissenting Stockholder's Appraisal Right, 77 HARV. L. REV. 1189, 1208-17 (1964) (discussing cases that hold the appraisal remedy exclusive).

In jurisdictions where the appraisal remedy is exclusive, courts should adjust appraisals, such as by including any rescissory damages that minority shareholders prove, in order to protect such shareholders from unfairness that falls short of fraud. See Thompson, Squeeze-Out Mergers and the "New" Appraisal Remedy, 62 WASH. U.L.Q. 415, 426 (1984) ("If courts intend to use appraisal to enforce fiduciary duties and not just to check managerial incompetence, courts and legislatures should adjust the standard for ascertaining value and the procedural requirements of the appraisal process .....").

7. See, e.g. N.Y. BuS. CORP. LAw $\S 623(\mathrm{k})$ (McKinney 1986) (appraisal remedy exclusive "unless the action is unlawful or fraudulent with respect to the shareholder or the corporation"); Weinberger, 457 A.2d at 714 (court can fashion appropriate equitable or monetary relief "where fraud, misrepresentation, self-dealing, dehiberate waste of corporate assets, or gross and palpable overreaching are involved"). Appraisal provides a concurrent remedy in these cases.

Other jurisdictions allow dissenting shareholders to bring parallel equitable actions to set aside transactions or, alternatively, to claim rescissory damages if transactions are unfair or involve selfdealing even if they are not necessarily fraudulent. See, eg., ILL. ANN. STAT. ch. 32, para. 11.65(b) (Smith-Hurd 1985) (equitable action warranted when "the action is fraudulent with respect to the shareholder" or there is a "breach of fiduciary duty owed to the shareholder"); ME. REV. STAT. ANN. tit. 13-A, $\$ 909$ (13) (shareholder may file a "demand for paynent of the fair value of his shares"); Coggins v. New England Patriots Football Club, Inc., 397 Mass. 525, 532-33, 536, 492 N.E.2d 1112, 1117-18, 1119-20 (1986) (allowing parallel equitable action when fiduciary duties are violated; granting rescissory damages); Rabkin v. Philip A. Hunt Chem. Corp., 498 A.2d 1099, 1104-05 (Del. 1985) (Weinberger, while broadly limiting collateral attacks on cash-out mergers, does not require that plantiff who seeks to bring equitable action allege nondisclosure or misrepresentation). But see Stemberg v. Amphica, Inc., 42 Cal. 3d 1198, 1206-07, 1209-14, 729 P.2d 683, 690-91, 693-94, 233 Cal. Rptr. 249, 255-56, 259 (1986) (no parallel equitable action, despite breach of fiduciary duty, where plaintiff knew of breach prior to merger). See generally 1 F.H. O'NEAL \& R. THOMPSON, supna note $4, \S 5.32$ (discussing split in judicial approaches).

8. Statutory provisions for cost-shifting may facilitate agreement. See Seligman, Reappraising the Appraisal Remedy, 52 GeO. WASH. L. REV. 829, $860-62$ (1984).

9. ReVised MOdel BusLness CoRP. ACT $\$ 13.30$ (1984). 
tion to be invoked only when the parties fail to reach reasonable terms of settlement. 10

Such statutes obviously favor negotiated valuation of shares. Promoting such settlements in practice, however, requires clarification of the valuation procedures that courts will apply when negotiation fails.

One aspect of valuation procedures that has confused courts and added uncertainty to this arca of law is the treatunent of minority shareholders' shares. In valuing noncontrolling shareholders' holdings, courts generally calculate the pro rata value of the shares first and then, as a second-stage adjustment, decide whether to reduce that pro rata value because the minority shareholders lack corporate decision-making power." This second-stage adjustment is known as a "minority discount." Not all jurisdictions have yet taken a clear position on whether or not to allow the minority discount, and those that have taken a position are spht. Courts in Iowa, Kentucky, Oregon, and Missouri have rejected the discount, ${ }^{12}$ while courts in Georgia, Indiana, Illinois, Kansas, and Mississippi have allowed it. ${ }^{13}$ Since this is an area of law in

10. Id. ch. 13 introductory comment.

11. See, eg., Atlantic States Constr, Inc. v. Beavers, 169 Ga. App. 584, 587, 314 S.E.2d 245, 250 (1984); Moore v. New Ammest, Inc., 6 Kan. App. 2d 461, 474-75, 630 P.2d 167, 177 (1981); see also Comment, Valuing Closely Held Stock: Control Premiums and Minority Discounts, 31 EMORY L.J. 139, 145 (1982) (minority discount is second-stage adjustment for valuing minority shares). Conrts that use only market price to calculate fair value do not make a second-stage adjustment, because market price itself captures any difference between the prices of controlling and noncontrolling shares. See, eg., Atlantic States, 169 Ga. App. at 589, 314 S.E.2d at 251; Moore, 6 Kan. App. 2d at 474-75, 630 P.2d at 177; see also Krishna, Determining the "Fair Value" of Corporate Shares, 13 CAN. Bus. LJ. 132, 168 (1987-1988) (use of publicly quoted stock prices implicitly discounts minority shareholdings).

12. See, eg., Richardson v. Palmer Broadcasting Co., 353 N.W.2d 374, 379 (Iowa 1984) (interpreting statute requiring payment of "fair value"); Woodward v. Quigley, 257 Iowa 1077, 1088-89, 133 N.W.2d 38, 44 (1965) (interpreting renewal statute requiring payment of "real value"); Ford v. Courier-Journal Job Printing Co., 639 S.W.2d 553, 556 (Ky. Ct. App. 1982) (interpreting statute requiring payment of "fair value"); King v. F.T.J., Inc., 765 S.W.2d 301 (Mo. Ct. App. 1988) (same); Dreiseszun v. FLM Indus., 577 S.W.2d 902, 905 (Mo. Ct. App. 1979) (same); Columbia Mgmt. Co. v. Wyss, 94 Or. App. 195, —, 765 P.2d 207, 214 (1988) (same). The Ford court did suggest, lowever, that it might use the involvement of a minority interest as a reason to "discard[]" the investment value approach, which most often leads to pro rata valuations. Ford, 639 S.W.2d at 556-57; see infra notes 38-39 and accompanying text (defining investment value).

13. See, eg., Hernando Bank v. Huff, 609 F. Supp. 1124, 1126-27 (N.D. Miss. 1985) (interpreting statute requiring payment of "fair value"), aff'd, 796 F.2d 803 (5th Cir. 1986); Perlman v. Permonite Mfg., 568 F. Supp. 222, 233-34 (N.D. Ind. 1983) (applying statute requiring payment of value of dissenting shares as determined by practice and procedure in conformity with state's eminent domain laws), aff'd, 734 F.2d 1283 (7th Cir. 1984); Atlantic States, 169 Ga. App. at 586, 314 S.E.2d at 249 (interpreting statute requiring paynent of "fair value"); Independence Tube Corp. v. Levine, 179 Ill. App. 3d 911, -, 535 N.E.2d 927, 930-31 (1989) (same); Moore, 6 Kan. App. 2d at 465-66, 630 P.2d at 171-72 (interpreting statute requiring payinent of shares' "value").

Other courts' positions remain unclear. See, eg., Bell v. Kirby Lumber Corp., 413 A.2d 137, 143 (Del. 1980) (no "rule of thumb" in valuing assets); Felder v. Anderson, Clayton \& Co., 39 Del. Ch. 76, 87, 159 A.2d 278, 285 (1960) (allowing 10\% discount from average-investment-value multi- 
which the "only things certain are the uncertainty, the delay, and the expense,"14 companies and shareholders everywhere will benefit from recognition of a general rule on minority discounts as second-stage adjustments.

This Note argues for general elimination of the minority discount as part of the appraisal remedy, a rule that would best reconcile managerial freedom and shareholders' expectations. The Note first describes the operation of the appraisal remedy, emphasizing the flexibility of the "fair value" standard. ${ }^{15}$ In part II, the Note argues that the remedy in large part aims to protect minority shareholders, and that a minority discount undermines this important goal. ${ }^{16}$ The Note suggests in part III that, concerns of fairness and minority protection aside, the discount proves difficult to calculate and unnecessary for prescrving managerial discretion. ${ }^{17}$ Finally, in part IV, the Note argues that the market exception to the appraisal remedy is compatible with pro rata valuation methods and does not compel acceptance of minority discounts. ${ }^{18}$ The Note concludes that to remain sensitive to both the concerns of the appraisal remedy and the need for managerial decision-making freedom, courts should reject the minority discount.

\section{The APPRAISAl REMEDY}

Many different types of corporate changes, including mergers, coinpulsory share exchanges, sales or exchanges of assets other than in the

plier to account for such factors "as the lack of marketability of the stock, etc."); Tri-Continental Corp. v. Battye, 31 Del. Ch. 523, 526-528, 74 A.2d 71, $72-73$ (1950) (value must be discounted because difficulty shareholder faces in withdrawing his pro rata investunent results in a "lower market value of the common stock in comparison with its net asset value"); American Gen. Corp. v. Camp, 171 Md. 629, 637, 190 A. 225, 228 (1937) (stating that dissenter is entitled to his "aliquot proportion," but not addressing whether that proportion involves minority discount).

If a corporation invokes the appraisal remedy to rebuff shareholders' demands for an involuntary dissolution, courts almost uniformly refuse to apply minority discounts. See, eg., Ronald v. 4 C's Elec. Packaging, Inc., 168 Cal. App. 3d 290, 298-99, 214 Cal. Rptr. 225, 230 (1985); Brown v. Allied Corrugated Box Co., 91 Cal. App. 3d 477, 485-87, 154 Cal. Rptr. 170, $175-76$ (1979); Raskin v. Walter Karl, Inc., 129 A.D.2d 642, 644, 514 N.Y.S.2d 120, 122 (1987); Blake v. Blake Agency, Inc., 107 A.D.2d 139, 149, 486 N.Y.S.2d 341, 349 (1985). But see McCauley v. Tom McCauley \& Son, 104 N.M. 523, 535, 724 P.2d 232, 244 (Ct. App. 1986). The rationale against discounts in these cases is, however, stronger. See infra note 63. But see Wysss 94 Or. App. at -, 765 P.2d at 213-14 n.8 (dissolution cases relevant, since statutory standard is same as in minority discount cases).

14. Manning, The Shareholder's Appraisal Remedy: An Escay for Frank Coker, 72 Yale L.J. 223, 233 (1962); see also Eisenberg, The Legal Roles of Shareholders and Management in Modern Corporate Decisionmaking, 57 CALIF. L. REV. 1, 85 (1969) (uncertainty and exposure discourage shareholders from invoking appraisal remedy).

15. See infra notes $19-48$ and accompanying text.

16. See infra notes $\mathbf{5 7 - 9 8}$ and accompanying text.

17. See infra notes 99-107 and accompanying text.

18. See infra notes $108-20$ and accompanying text. 
regular course of business, and certain amendments to articles of incorporation, trigger dissenters' rights statutes. ${ }^{19}$ In addition, corporations may specify other triggering transactions by resolution or by provisions in their bylaws or articles of incorporation. ${ }^{20}$ When triggering transactions occur, dissenters can seek protection under their state's dissenters' rights statute.21

19. All jurisdictions specify merger as a triggering transaction, twenty-four jurisdictions specify compulsory share exchange, forty-four jurisdictions specify sale or exchanges of assets, and twentythree specify certain amendments to articles. See REVISED MODEL BUS. CORP. ACT ANN. $\$ 13.02$ annot. (1984) (listing various jurisdictions' triggering transactions as of Nov. 30, 1987); MISS. CODE ANN. $\$$ 79-4-13.02 (Supp. 1988) (specifying triggering transactions as of Jan. 1, 1988). A de facto merger can also trigger the appraisal remedy. See eg., Morkey Bros. v. Clark, 139 Mich. App. 193, 195-96, 361 N.W.2d 763, $764-65$ (1984) (granting appraisal remedy where stock values diminished by corporation's issuance of $400 \%$ more stock).

20. Revised Model Business CoRp. ACt $\$ 13.02(a)(5)$ (1984). Eleven jurisdictions allow corporations to specify triggering transactions for themselves. See, e.g., Miss. CoDE ANN. \$ 79-413.02 (effective Jan. 1, 1988); Seligman, supra note 8, at 833 (listing jurisdictions as of 1984). Shareholders also seek appraisals in many contexts other than dissenters' rights hitigation. See, eg., Quick v. Campbell, 412 So. 2d 264, 266-67 (Ala 1982) (contractual clause requiring corporate repurchase of employec's shares); infra note 94 (discussing valuation of stock for estate and gift tax purposes). When valuing shares that are subject to a stockholder agreement, courts should focus on the presumed intention of the parties. When making statutorily required valuations, courts should examine legislative intent. See Atlantic States Constr., Inc. v. Beavers, 169 Ga. App. 584, 585, 314 S.E.2d 245, 248 (1984).

21. See Ala. CODE $\S 10-2 A-163(c)$ (1987); Alaska Stat. $\$ 10.05 .456$ (1985); ARIz. Rev. Stat. ANN. $\S 10-081($ ) (1977); ARK. Stat. ANN. \$ 4-26-1007(f)(1) (1987); Cal. Corp. COde \$1304 (West 1977); Colo. Rev. STat. \$ 7-4-123-24 (1986); CoNN. GeN. STat. ANN. \$ 33-374(g) (West 1987); DEL. CODE ANN. tit. 8, $\$ 262$ (Supp. 1988); D.C. CODE ANN. \$ 29-373 (1981); FrA. STAT. ANN. \$ 607.247 (West 1977 \& Supp. 1988); GA. CODE ANN. \$ 14-2-25I (1982); HAWAII REv. STAT. $\$ 415-81$ (1985 \& Supp. 1987); IDAHO CODE $\$ 30-1.81$ (1980); ILI. ANN. STaT. ch. 32, para. 11.70 (Smith-Hurd 1985); IND. CODE ANN. \$23-1-44-19 (Burns Supp. 1988); IowA CODE ANN. $\$ 496 A .78$ (West 1962); KAN. STAT. ANN. $\$ 17-6712$ (c), (c) (1981); KY. REV. STAT. ANN. $\$ 271$ A.405 (Baldwin 1983); LA. REv. STAT. ANN. $\$ 12: 131$ (West 1969 \& Supp. 1988); ME. REV. STAt. ANN. tit. 13-A, $\$ 909$ (1981); MD. CORPS. \& ASS'NS CODE ANN. $\$ \S 3.208,3-210$ (1985); Mass. Gen. L. ch. 156B, $\$ \S 90-91$ (1979); Mich. Comp. LAWS ANN. \$\$ 450.1767, .1768a (West Supp. 1988); MINN. STAT. ANN. \$ 302A.473 (West 1985 \& Supp. 1989); MISS. CODE ANN. \$ 79-413.02 (Supp. 1988); Mo. ANN. STAt. $\$ \S 351.405$, .455 (Vernon 1966 \& Supp. 1989); MONT. CODE ANN. \$ 35-1-812 (1987); NeB. REv. STAT. \$21-2080 (1987); NEv. REv. STar. ANN. \$78.510 (Michie 1986); N.H. Rev. Stat. ANN. § 293-A:82 (1987); N.J. STat. ANN. §§ 14A:11-7, -8, (West 1969); N.M. STAT. ANN. § 53-15-4 (1978); N.Y. Bus. CoRp. LAW $\$ 623$ (McKinney 1986); N.C. Gen. Stat. $\$$ 55-113 (1982); N.D. CENT. CODE $\$ 10-19.1-87$ to -88 (1985); Ohlo ReV. CODE ANN. $\S 1701.85$ (Anderson 1985); ORLA. STAT. ANN. tit. 18, § 1091 (West 1986 \& Supp. 1989); OR. Rev. STAT. $\$ \S 60.587, .591$ (1988); PA. STat. ANN. tit. 15, $\$ 1515$ (Purdon 1967 \& Supp. 1988); R.1. Gen. LAws § 7-1.1-74 (1985); S.C. CODE ANN. § 33-11-270 (Law. Co-op. 1987); S.D. Codified LAws ANN. $\$ \S 47-6-48$, -50 (Supp. 1988); TENN. CODE ANN. $\$$ 48-23-102 (1988); TeX. Bus. CoRp. ACT ANN. arts. 5.12, .16 (Vernon 1980 \& Supp. 1989); UTAH CODE ANN. § 16-10-76 (1987); VT. STAT. ANN. tit. 11, $\S 2004$ (1984); VA. CODE ANN. $\$ \S 13.1 .739$ to -740 (1985); WASH. REV. CODE ANN. § 23A.24.040 (1969 \& Supp. 1989); W. VA. CODE § 31-1-123 (1988); Wis. STAT. ANN. § 180.72(6) (West 1957 \& Supp. 1988); Wyo. STar. $\$ 17-1-504$ (1977); P.R. LAwS ANN. tit. 14, $\S 1906$ (1976); V.I. CODE ANN. tit. 13, §256 (1982). 
Most state statutes, along with the Revised Model Business Corporation Act, provide that shareholders who dissent from a fundamental corporate change will receive the "fair value" of their shares if they comply with certain procedural requireinents. ${ }^{22}$ The Model Act defines fair value as "the value of the shares immediately before the effectuation of the corporate action to which the dissenter objects, excluding any appreciation or depreciation in anticipation of the corporate action unless exclusion would be inequitable." 23 Far froin having a comprehensive definition, "fair value" remains a construct that parties and courts can fill with meaning. ${ }^{24}$

Courts determine "fair value" under either the "Delaware block method"2s or under the more comprehensive valuation standard articulated by the Delaware Supreine Court in Weinberger v. UOP, Inc. ${ }^{26}$ Under the Delaware block method, courts consider three aspects of a corporation's value: market value, net asset value, and investment value. ${ }^{27}$ Market value is the price at which willing buyers and sellers would trade a corporation's shares. ${ }^{28}$ Net asset value states the value of a corporation's shares as if the corporation ceased business, sold its assets piece-by-piece, and divided the proceeds proportionately anong its shareholders. ${ }^{29}$ This value reflects an appraisal of the iteins on a corpo-

22. Normally dissenters inust (1) give advance notice that they intend to dissent, (2) refrain from voting in favor of the corporate action, and (3) demand payment and tender their certificates. See, eg., REvised MOdel Bus. CoRP. Act $\$ \S 13.20-.28$. As the Model Act provides:

If a demand for payment under section 13.28 remains unsettled, the corporation shall commence a proceeding within 60 days after receiving the payment demand and petition the court to determine the fair value of the shares and accrued interest. If the corporation does not commence the proceeding within the 60-day period, it shall pay each dissenter whose demand remains unsettled the amount demanded.

Id § 13.30(a). Other statutes use such terms as "value," eg., KAN. STAT. ANN. 17-6712 (1981 \& Supp. 1987), or "fair market value," e.g., CAL. CORP. CODE $\S 1301$ (West 1977 \& Supp. 1989).

23. REVISED MODEL BUS. CORP. ACT $\$ 13.01(3)$; see infra note 43.

24. Id. $\$ 13.01$ comment 3 ("The definition of 'fair value' in section 13.01(3) leaves to the parties (and ultimately to the courts) the details by which 'fair value' is to be determined within the broad outlines of the definition.").

25. See, eg., Woodward v. Quigley, 257 Iowa 1077, 1082, 133 N.w.2d 38, 40, modified on reh'g, 257 Iowa 1104, 136 N.W.2d 280 (1965); Moore v. New Ammest, Inc., 6 Kan. App. 2d 461, 466, 630 P.2d 167, 172 (1981); In re Valuation of Common Stock of Libby, McNeill \& Libby, 406 A.2d 54, 60 (Me. 1979).

26. 457 A.2d 701, 713 (Del. 1983) (parties may prove value by any technique considered acceptable in the financial community and otherwise admissible in court); see infra notes $37-43$ and accompanying text.

27. See Universal City Studios, Inc. v. Francis I. duPont \& Co., 334 A.2d 216, 218 (Del. 1975); Libby, 406 A.2d at 60 .

28. Hemando Bank v. Huff, 609 F. Supp. 1124, 1127 (N.D. Miss. 1985), aff'd, 796 F.2d 803 (5th Cir. 1986).

29. 12B W. FLETCHER, supra note $1, \S 5906.14$. Asset value might also be viewed in a broader sense as "going concern" value. See Tri-Continental Corp. v. Battye, 31 Del. Ch. 523, 526, 74 A.2d 71,72 (1950) (asset value states proportionate interest in a "going concern," not a liquidation value). 
ration's balance sheet, i.e., the difference between the corporation's liabilities and its assets. ${ }^{30}$ Investment value, on the other liand, looks to the future and measures a corporation's earning capacity:

Investment value is fixed in a two-step process. First, based on the corporation's recent earnings history, an average annual earnings figure is calculated. In arriving at this figure, one must select a period of years of sufficient length to assure an adequate data base .... The second step ... is to select a capitalization ratio, or earnings multiplier. The product of the capitalization ratio and the average annual earnings figure yields the investment value of the corporation .... ${ }^{31}$

Depending on the circumstances, courts will give the three aspects of a corporation's value varying weights. ${ }^{32}$ If an active market for a corporation's shares exists; courts might use market value as the "fair value" of minority shares.33 Courts would hesitate to consider market value, however, in a case involving a thin market riddled with insider transactions. ${ }^{34}$ - In liquidation cases, courts would most likely look to net asset value to ascertain fair value: upon hquidation, all sliareholders are entitled to receive ratable sliares of a corporation's value and because liquidation renders market price irrelevant and future earning capacity a nullity, these measurements of value cannot contribute to a meaningful

30. See Perlman v. Permonite Mfg. Co., 568 F. Supp. 222, 223 (N.D. Ind. 1983). However, a court can use other means to calculate asset value. See Seligman, supra note 8, at 847-49.

31. Libby, 406 A.2d at 65.

32. See, eg., Hernando Bank, 609 F. Supp. at 1127 (courts should examine variety of factors in determining fair value); $L i b b y, 406$ A.2d at 60 ("The weighting of these interdependent elements of fair value is more akin to an artistic coniposition than to a scientific process."); see also Note, Valuation of Dissenters' Stock Under Appraisal Statutes, 79 HARV. L. REv. 1453, 1457 (1966) ('The elements of value must be weighed in different proportions, depending on the nature of the particular firm, the industry in which it operates, general economic conditions, and other similar variables.").

33. 12B W. FLETCHER, supra note $1, \S 5906.13$; see, eg., Armstrong v. Marathon Oil Co., 32 Ohio St. 3d 397, 412, 513 N.E.2d 776, 790 (1987) (statute construed to define "fair cash value" as market value where there is "significant trading activity"). But see Columbia Mgmt. Co. v. Wyss, 99 Or. App. 195, -, 765 P.2d 207, 212 (1988) (fair value enconipasses more than market value even if stock traded on national security exchange). This is especially true when state statutes call for a determination of "market value" or "fair market value" See Libby, 406 A.2d at 60 n.5; Annotation, Valuation of Stock of Dissenting Stockholders in Case of Consolidation or Merger of Corporation, Sale of its Assets, or the Like, 48 A.L.R. 3d 430, 438 (1973).

Almost half of the state statutes contain a market exception to the appraisal remedy: they do not allow valuation procedings for shares of a publicly held company. REVISED MODEL BUSINESS CORP. ACT ANN. § 13.02 annot. (1984). In these cases, legislatures have assumed that there is an active and efficient market in the securities. Id; see infra notes 108-20 and accompanying text. But See ReVISED MODEL Business CORP. ACT ch. 13 (1984) (no market exception).

34. See, e.g., Francis I. duPont \& Co. v. Universal City Studios, Inc., 312 A.2d 344, 352 (Del. Ch. 1973) (market value too speculative to be included in valuation), aff'd, 334 A.2d 216 (Del. 1975); Ford v. Courier-Journal Job Printing Co., 639 S.W.2d 553, 555 (Ky. Ct. App. 1982) (market value not considered where transactions in shares "were infrequent, not current and involved officers of the [c]ompany"). But see Hernando Bank, 609 F. Supp. at 1127 (market price "significant" despite relatively thin trading consisting mostly of insider transactions). 
valuation. Absent liquidation, lowever, most courts give net asset value little weight. ${ }^{35}$ Investment value is most important when the business in question will contmue as a going concern and no reliable market value exists. ${ }^{36}$

Over the past few years, courts have noved from the Delaware block inethod to the inore coinprehensive standard established in Weinberger v. UOP, Inc ${ }^{37}$ Under the Weinberger standard, courts inust consider "all relevant factors" in valuing shares; they may use any technique that is considered acceptable in the financial community or is otherwise admissible in court. ${ }^{38}$ Although the calculation still includes market value, investment value, and asset value, it encoinpasses other factors as well. ${ }^{39}$ The Weinberger court narrowly interpreted the language of the Delaware dissenters' rights statute, which excludes from appraisal calculations any "value arising froin the accoinplishment or expectation of [a] inerger," 40 as excluding only speculative elements of value arising froin a merger. ${ }^{41}$ This interpretation allows courts to consider all elements of future value that are known or provable at the time of a merger. ${ }^{42}$ Furthermore, Weinberger allows appraisal calculatious to include rescissory damages if such damages are "appropriate to all the issues of fairness." 43

35. See Hermando Bank, 609 F. Supp. at 1128 (rejecting net asset value approach); Libby, 406 A.2d at 66 ("Generally net asset value should not be heavily weighted in stock valuation unless the valuation is being made for hiquidation purposes."); see also Annotation, supre note 33, at 438 (net asset or hiquidation value rarely taken into account except as minimum value). See generally Seligman, supra note 8, at 848-50 (Delaware cases fail to define net asset value consistently); Note, supro note 32 , at 1460 (discussing application of net asset value). (1982).

36. Haynsworth, Valuation of Business Interests, 33 MERCER L. REV. 457, 508-09 \& nn.174-75

37. 457 A.2d 701, 713 (Del. 1983). In Weinberger, minority stockholders of a corporate subsidiary attacked the validity of a merger with the subsidiary's parent corporation. Two of the subsidiary's directors were members of the parent's board, and although they knew that the price offered did not represent the best bid the parent would make, they failed to disclose this information to the subsidiary. Id. at 707. The court noted that the subsidiary might have obviated the problem by appointing a group of outside directors to negotiate with the parent at arm's length. Id. at $709 \mathrm{n} .7$. The court remanded the case to the chancery court to test the fairness of the $\$ 21$ price by taking into account all the relevant factors.

38. Id. at 713; see also Blake v. Blake Agency, Inc., 107 A.D.2d 139, 146-47, 486 N.Y.S.2d 341, 347-48 (1985) (listing several methods courts can legitimately use to determine "fair value").

39. See Rosenblatt v. Getty Oil Co., 493 A.2d 929, 940 (Del. 1985) (Weinberger did not eliminate the Delaware block approach, "only its exclusivity as a tool of valuation"); see also 1 F.H. O'NEAL \& R. THOMPSON, supre note 4, § 5.31, at 194 (Weinberger approach is "more flexible" than Delaware block method and allows appraisals to "more nearly accord with the real value of ... shares").

40. DEL. CODE ANN. tit. 8, § 262(h) (1983).

41. Weinberger, 457 A.2d at 713; see also Alpert v. 28 Williams St. Corp., 63 N.Y.2d 557, 571, 473 N.E.2d 19, 27, 483 N.Y.S.2d 667,675 (1984).

42. Weinberger, 457 A.2d at 713 .

43. Id. at 714; see also Herzel \& Colling, Establishing Procedural Faimess in Squeeze-Out Mergers After Weinberger v. UOP, 39 Bus. LAW. 1525, 1531 (1984): 
As recent cases have indicated, the "fair value" standard used in dissenters' rights statutes leaves courts plenty of discretion as they apply the appraisal remedy. ${ }^{44}$ Without a comprehensive statutory definition of fair value, ${ }^{45}$ courts valuing minority shares can look both to legislative intent ${ }^{46}$ and to general conceptions of fairness. ${ }^{47}$ Courts should use this broad interpretive authority to achieve just results in individual cases, ${ }^{48}$ but they can better achieve such flexibility by altering the mix of valuation factors, not by applying a second-stage adjustment to minority interests.

\section{How the Minority Discount Undermines the Protective PURPose OF THE APPRAISAL REMEdY}

\section{A. Protecting Minority Shareholders' Expectations}

The appraisal remedy should not penalize majority shareholders for exercising majority rule and directing a corporation's business. Instead, the appraisal remedy should focus on protecting minority shareholders' legitimate expectations against majority oppression and management misconduct. ${ }^{49}$ In evaluating minority shareholders' expectations, courts should consider the investment those shareholders have made in the corporation at issue, as well as their entitlement to pro rata distributions from the corporation.

1. A Historical Perspective. According to the traditional rationale, dissenters' rights legislation offers minority shareholders a quid pro

\footnotetext{
Rescissory damages essentially give a plaintiff the option of having the value of the stock he has given up in the merger calculated either as of the time the damage award is made or at the time of the transaction. In theory he is being given the option to take back his stock and resell it to the defendant at current (date of the hearing) values or to take the value of the stock at the time of the transaction.
}

44. See Note, Dissenting Stockholder's Right of Appraisal-Determination of Value, 28 N.Y.U. L. REV. 1021, 1022 (1953) (effectiveness of appraisal remedy depends on meaning courts give the word "value").

45. See supna note 24.

46. See, eg., Atlantic States Constr., Inc. v. Beavers, $169 \mathrm{Ga}$ App. 584, 585.86, 314 S.E.2d 245, 248-49 (1984); Columbia Mgmt. Co. v. Wyss, 94 Or. App. 195, -, 765 P.2d 207, 214 (1988).

47. See Dreiseszan v. FLM Indus., 577 S.W.2d 902, 907 (Mo. Ct. App. 1979) (underlying purpose of appraisal remedy is to give dissenters an "equitable, just, and 'fair value' "); $c f$. Sarrouf $v$. New England Patriots Football Club, Inc., 397 Mass. 542, 551, 492 N.E.2d 1122, 1129 (1986) (appraisal is an equitable proceeding).

48. See Atlantic States, $169 \mathrm{Ga}$. App. at 586, 314 S.E.2d at 249 (amorphous term "fair value" is intended to allow flexible response to particular fact situations).

49. See Fischel, The Appraisal Remedy in Corporate Law, 1983 AM. B. Found. REs. J. 875, 876-81 (from ex ante perspective, appraisal most useful when majority shareholders are more likely to appropriate wcalth from minority shareholders than to maximize corporate wealth). 
quo for the loss of their veto power over fundamental corporate change.so Historically, minority shareholders could exercise the veto power to block transactions that fundamentally altered their interest in a corporation. ${ }^{51}$ That power protected minority shareholders' original expectations regarding their shares-the risks they accepted and the nature of the investment they planned to inake.52 With the demise of the veto power, majority shareholders could effect major corporate changes despite minority objections. Although minority shareholders could no longer stop objectionable transactions, dissenters' rights statutes gave them a right to withdraw their investments from a corporation on fair terms, search for suitable places to reinvest their funds, and reassert control over the nature and risks of their investments. If they wanted instead to assume the risks associated with the new venture planned by the majority, they could simply accept the new securities that the majority offered.

This background of the common law veto power, which vested substantial power in minority shareholders, has persuaded soine courts to exclude minority discounts from the current appraisal reinedy. These courts argue that a discount fails to honor minority shareholders' legitimate expectations concerning the value of their investments. In Dreiseszun v. FLM Industries, for example, the Missouri Court of Appeals refused to discount the minority shares at issue, stressing that "this Court recognizes that prior to the enactment of this 'judicial appraisal' statute, the unanimous consent of all the shareholders in a corporation was required to authorize the transfer of . . . assets."53 Similarly, in Woodward v. Quigley, the Supreme Court of Iowa disallowed a iminority discount, noting that the Iowa appraisal statute resembled statutes enacted "to modify the common-law rule which required unamimous consent of all the stockholders for a substantial change in the corporate structure." 54

Courts that view the appraisal remedy as a quid pro quo for the veto power do not presume that shareholders' investments will remain static; they recognize that contemporary investors anticipate changes in their

50. Voeller v. Neilston Warehouse Co., 311 U.S. 531, 535 n.6 (1941); Chicago Corp. v. Munds, 20 Del. Ch. 142, 149, 172 A. 452, 455 (1934).

51. See supra notes 1-2 and accompanying text.

52. Id.

53. 577 S.W.2d 902, 907 (Mo. Ct. App. 1979); see also Flarsheim v. Twenty Five Thirty Two Broadway Corp., 432 S.W.2d 245, 252 (Mo. 1968) (warning against "weaken[ing] or fritter[ing] away by construction the protection given minority shareholders in exchange for dispensing with the necessity of securing unanimous consent of the shareholders for the sale of . . . assets").

54. 257 Iowa 1077, 1086, 133 N.W.2d 38, 42, modified on reh'g, 257 Iowa 1104, 136 N.W.2d 280 (1965). 
investments. 55 These courts therefore seek to uphold legitimate expectations of fair dealing and full disclosure, not outmoded expectations of corporate immutability. ${ }^{56}$ Under this approach, courts emphasize the historical derivation of dissenters' rights statutes only to demonstrate that legislatures have long attached importance to protecting the interests and expectations of minority shareholders.

2. Pro Rata Investment and Pro Rata Disbursement. When shareholders make pro rata investments in a corporation or constructively contract to receive pro rata distributions some time in the future, they legitimately expect to get pro rata value back. ${ }^{57}$ In closely held corporations, one context im which the appraisal remedy takes on special importance, ${ }^{58}$ shareholders often will have made pro rata investments at start-up. ${ }^{59}$ Even if shareholders have purchased their shares in the market, a pro rata division can still occur at some point in the future-either completely, in a voluntary dissolution, or partially, through a distribution of dividends. 60

When a ready market value is unavailable, a court applying the appraisal remedy can determine fair price under a net asset value approach by dividing the greater of a company's going concern value or its hquida-

55. See, eg., Hariton v. Arco Elecs., 40 Del. Ch. 326, 332, 182 A.2d 22, 26 (1962) (shareholder anticipated having to accept "new investment"), aff'd, 41 Del. Ch. 74, 188 A.2d 123 (1963); see also Folk, De Facto Mergers in Delaware: Hariton v. Arco Electronics, Inc., 49 VA. L. REV. 1261, 128081 (1963) (shareholders invest in continuous course of business that changes over time).

56. Most cases involving dissenters' rights state the rationale for such rights broadly. As the Supreme Court stated in Voeller v. Neilstou Warehouse Co., 311 U.S. 531, 535 n.6 (1941) (emphasis added):

At common law, unanimous shareholder consent was a prerequisite to fundamental changes in the corporation. This made it possible for an arbitrary minority to establish a nuisance value for its shares by refusal to cooperate. To nueet the situation, legislatures authorized the making of changes by majority vote. This, however, opened the door to victimization of the minority. To solve the dilemma, statutes permitting a dissenting minority to recover the appraised value of its shares were widely adopted.

57. See Columbia Mgmt Co. v. Wyss, 94 Or. App. 195, -, 765 P.2d 207, 212 (1988) (fair value should refiect dissenters' loss of opportunity to share in corporate prospects).

58. Most close corporations escape the market exception to the appraisal remedy, see infra notes $110-20$ and accoinpanying text, because their shares are not generally traded in the securities markets. F.H. O'Neal \& R. ThOMPSON, ClOSE CoRporations $\S 1.02$ (3d ed. 1987).

59. This fact counters the argument, made by some courts and cominentators, that minority shareholders awarded pro rata value receive something for which they have not paid. See, eg., Atlantic States Constr., Inc. v. Beavers, 169 Ga. App. 584, 589, 314 S.E.2d 245, 251 (1984) (valuation process focuses on value of stock held by dissenting shareholder, not on percentage of corporate worth); $c f$. Seligman, supra note 8, at 848 (dissenter entitled to proportionate interest in "going concern," not proportionate interest in liquidation value).

60. To the extent that mariet price does not refiect a minority discount, such shareholders are in a position identical to the position of shareholders who make pro rata investments at start-up. See infra text accompanying note 120 . 
tion value equally among all shares. ${ }^{61}$ This method of valuation constructively dissolves the company: the minority shareholders receive a share of the corporation equal to what they would receive if the whole enterprise were dissolved (either sold as a going concern or liquidated) and a new enterprise begun. Constructive dissolution comports with the traditional view of equity securities, according to which each share of a corporation represents a pro rata interest in the corporation's assets and going concern value. As one court said of this traditional view: "A common stockholder is an owner of the enterprise in proportion that his stock bears to the entire stock and ordinarily he is entitled to participate in the management, profits and ultimate distribution of assets of the corporation."62 Further, to the extent that shareholders' expectations follow this traditional view, constructive dissolution fulfills those expectations.

In fact, however, courts too often ignore the possibility of pro rata distribution except in extraordinary circumstances, such as when shareholders' proposed course of action will lead to a voluntary or involuntary dissolution. ${ }^{63}$ Courts should recognize that receiving pro rata value and obtaining pro rata disbursements are legitimate expectations that must be upheld. Any other approach to valuation in effect awards majority shareholders a control premium. ${ }^{64}$

61. See supra note 29 and accompanying text. Courts can use this approach even under the Weinberger valuation standard. See supra note 39 and accompanying text.

62. See Dreiseszun v. FLM Indus., 577 S.W.2d 902, 908 (Mo. Ct. App. 1979) (quoting 18 C.J.S. Corporations $\S 216$, at 648 (1939)).

63. In some states, a corporation, a majority shareholder, or any other shareholder may elect to buy out a shareholder who has filed a petition of dissolution; the price of such a buy out is the fair value of the shareholder's shares. See, eg., CAL. CORP. CODE $\$ 2000$ (a) (West 1977 \& Supp. 1989); N.Y. Bus. CoRP. LAW § 1118(a) (McKinney Supp. 1989). The California provision instructs courts to determine fair value "on the basis of the liquidation value as of the valuation date but taking into account the possibility, if any, of sale of the entire business as a going concern in a liquidation." CAL. CORP. CODE $\S 2000$ (a). The New York statute instructs courts to find only the fair value of the shares in question. N.Y. Bus. CORP. LAw § 1118(b).

In dissolution cases, strong reasons support the use of pro rata value without a discount for minority shares. A minority shareholder seeking dissolution claims that majority shareholders have engaged in some unfair, possibly tortious, action. If the minority shareholder succeeds in having the company dissolved, all shareholders will receive their pro rata share of the assets, with no account given to the minority status of their shares. Minority shareholders should not receive less than this value if, instead of fighting the dissolution action, the majority decides to seek appraisal of minority shares in order to buy out the minority and reduce corporate discord.

Even though the rationale against discounting is very strong in dissolution actions, the same potential for realizing a corporation's pro rata value inheres in any dissenters' rights situation. Although the possibility of dissolution may be more attenuated, courts nonetheless should recognize that such a possibility exists.

64. Some cominentators have argued that a company should recover any premium over market value paid to a controlling shareholder and treat that premium as a corporate asset. See A. BERLE \& G. Means, The Modern Corporation and Private Property 243-44, 247-49 (1932). If 


\section{B. Protecting Minority Shareholders from Unfairness}

The appraisal remedy has the virtue of protecting shareholders' expectations regarding the nature of stock ownership and their shares' subjective value ${ }^{65}$ In addition, it provides a "net of protection" against unfairness that falls short of triggering other remedies available to shareholders and deals with situations in which shareholders forgo such remedies. 66 In interpreting appraisal statutes, courts must extend this net of protection to minority shareholders facing new challenges, such as cashout mergers.

1. Voluntariness Minority shareholders resort to the appraisal remedy partly as the result of coercion. In some cases, minority shareholders have a limited choice between joining a fundamentally transformed venture or leaving the corporation; in others, a merger plan or compulsory share acquisition statute requires them to relinquish their shares. ${ }^{67}$ When minority shareholders sell their shares on the market, they clearly choose the market price over an interest in the corporation, even if that market price in some way discounts the value of their shares. Dissenters, on the other hand, do not voluntarily enter the market and should not have to endure its vagaries. Rather, they should receive every benefit of the doubt regarding the value of their shares. ${ }^{68}$

courts accepted this "activist" remedy, then they would certainly use pro rata value when applying the more passive appraisal remedy. See, eg. Brown v. Allied Corrugated Box Co., 91 Cal. App. 3d 477, 487 n.8, 154 Cal. Rptr. 170, 176 n.8 (1979) (many commentators believe that courts should treat control premiums as a corporate asset).

65. See Jones v. H.F. Ahmanson \& Co., 1 Cal. 3d 93, 117, 460 P.2d 464, 478, 81 Cal. Rptr. 592, 606 (1969) ("Appraisal rights protect the dissenting minority shareholder against being forced to either remain an investor in an enterprise fundamentally different than that in which he invested or sacrifice his investment by sale of his shares at less than a fair value.").

Current market prices normally induce only a small percentage of a total body of stockholders to sell It is impossible to know what value shareholders place on retained shares and, consequently, the average subjective value of all shares outstanding. A truly accurate average valuation of shares would thus exced the current market price. See Kanda \& Levmore, The Appraisal Remedy and the Goals of Corporate Law, 32 UCLA L. REV. 429, $437-48$ (1985) (because all shareholders do not " "appreciate' their shares identically," market price "understates their average valuation").

66. See State ex rel. Robbins v. Shellsburg Grain \& Lumber Co., 243 Iowa 734, 739, 53 N.W.2d 143,145 (1952) (statute's purchase clause intended to protect minority shareholders against "rough. shod tactics upon the part of a majority group"); Raskin v. Walter Karl, Inc., 129 A.D.2d 642, 644, 514 N.Y.S.2d 120, 122 (1987) (stating, in involuntary dissolution case, that appraisal statutes are designed "to protect a minority shareholder from any unjust exercise by the majority shareholders of their greater power" $)$.

67. See, eg., Mo. CORPS. \& Ass'NS CODE ANN. \$ 3-105 (1985). See generally 1 F.H. O'NEAL \& R. THOMPSON, supra note $4, \S 5.07$ (describing procedure for coinputing share exchanges).

68. See Haynsworth, supra note 36, at 459; Columbia Mgmt. Co. v. Wyss, 94 Or. App. 195, -, 765 P.2d 207, 214 (1988) (dissenters who have little choice but to exercise their statutory rights would not be adequately protected by market value approach). 
Minority shareholders "cashed out" by the majority are particularly vulnerable to coercion. In this type of fundamental corporate change, minority shareholders cannot choose between taking part in a new venture or receiving the fair value of their shares. When majority shareholders approve such a transaction, manageinent can pay the minority with cash or non-equity securities and refuse to issue shares in any new corporation that results from the transaction. ${ }^{69}$ The choice whether minority shareholders will remain part of a new enterprise shifts from minority to majority, and the appraisal remedy must then set the minimum price at wlich the transaction can proceed.70

The coerciveness of this shift of choice increases the potential for abuse and calls for the same type of solicitude given to minority shareholders' expectations about the fundamental character of their investments. Here the protection is not absolute-the cash-out will proceedbut the price of the merger's consummation will be the return of the minority's pro rata value in the corporation. This guarantee of pro rata value serves the interests of corporate democracy by granting the minority greater bargaining power, counterbalancing the majority's ability to set an initial price for the minority shares. In a properly functioning dissenters' rights process, the parties' negotiations will lead to a coinpromise casll-out price somewhere between the corporation's offer and the higher appraisal price. ${ }^{71}$

2. Minority Shareholder Oppression. Minority shareholders do not seck appraisal just because the nature of their investınent has changed. They will resort to the unwieldy and costly appraisal remedy only if they perceive that the majority has acted unjustly, ${ }^{72}$ sucli as by offering a price significantly below the value of the minority's shares or by causing a decline in the value of those shares. Although legislatures

69. See 1 F.H. O'NEAL \& R. THOMPSON, supra note 4, § 5.04, at 22-23.

70. Id. $\S 5.28$, at 170; see also In re Bird Precision Bellows Ltd., 1984 Ch. 419, 430 (stating, in regard to minority oppression remedy under English Companies Act, 1980, § 75, that "it would not merely not be fair, but most unfair, that [a minority shareholder] should be bought out on the fictional basis applicable to a free election to sell his shares").

71. The high cost of seeking an appraisal remedy, see infra note 72 , induces a minority shareholder to negotiate with a majority rather than pressing for a court appraisal that would net only a slightly higher pro rata value.

72. Eisenberg, supra note 14, at 85 . Minority shareholders who seek an appraisal remedy risk accumulating a large bill for attorneys' fees and expert witnesses. 15 W. FLETCHER, supra note 1, $\S 7165$ (1983). For example, the Weinberger court demied the plaintiffs costs for depositions, trave1 and other expenses. Weinbenger, $517 \mathrm{~A} .2 \mathrm{~d}$ at 656; see also Stemberg v. Amplica, Inc., $42 \mathrm{Cal}$. 3d 1198, 1219-20, 729 P.2d 683, 697-98, 233 Cal. Rptr. 249, $262-63$ (1986) (Bird, C.J., dissenting) (appraisal remedy ineffective because of its complex costs and procedures); Seligman, supra note 8, at 856-64 (arguing that appraisal procedures are mostly unnecessary and that risk of bearing court costs and appraisers' expert witnesses' and attorneys' fees is unreasonable). 
did not design the appraisal remedy to counter "fiduciary misbehavior,"73 oppressed minority shareholders may find an appraisal the only or, at best, the least dangerous remedy available. ${ }^{74}$ Thus, minority shareholders invoke the appraisal remedy in part because of necessity.

The appraisal remedy combats two types of minority oppression: (1) discernible corporate misbehavior in such transactions and (2) general unfairness in the minority/majority relationship that is difficult to prove or expensive to litigate. 75 Both of these forms of oppression conflict with the fiduciary duties that majority sharelolders owe minority shareholders under state laws; they also reduce minority share prices by diverting corporate benefits to the majority. ${ }^{76}$

Fiduciary obligations limit majority shareholders' ability to act to the detriment of a corporation ${ }^{77}$ and its minority shareholders, ${ }^{78}$ or to divert corporate opportunities ${ }^{79}$ and thereby enhance the value of major-

73. Brudney \& Chirelstein, Fair Shares in Corporate Mergers and Takeovers 88 HARv. L. REv. 297, 304-07 (1974).

74. See, eg. Columbia Mgnt. Co. v. Wyss, 94 Or. App. 195, -, 765 P.2d 207, 214 (1988) (statutory remedy most viable option for dissenter); see also supra notes 6-7 and accompanying text (discussing exclusivity of appraisal rights). Even if collateral action could remedy specific instances of fiduciary breach, general unfairness in the minority/majority relationship will persist. See infra note 76 and accompanying text. One option available when the corporation itself has been harmed-the derivative suit-is fraught with complications. Standing requirements, indemnification provisions, and other impediments seriously limit the likelihood that a derivative suit will result in a net gain for the company. See generally D. DEMotT, Shareholder Derrvative ACrions (1987) (comprehensive diseussion of substantive and procedural aspects of derivative suits).

75. By denying a minority discoimt in cases of oppression by majority shareholders, courts protect minority shareholders in general by discouraging majorities from using oppressive tactics. See supra note 66 and accompanying text; see also 1 F.H. O'NEAI \& R. THOMPSON, supre note 4, $\$ 5.31$, at 194 ("[T]he danger of exploitation ... remains to the extent that legislators or the courts do not adjust the valuation formula from time to time to reflect changing economic theories and perceptions about imtrinsic worth of stock."); Eisenberg, supra note 14, at 84-86 (appraisal remedy forces management to formulate deal acceptable to large number of shareholders).

76. See Brudney, Efficient Markets and Fair Values in Parent Subsidiary Mergers, 4 J. Corp. L. 63, 69 (1978).

77. See Perlman v. Feldmann, 219 F.2d 173, $175-76$ (2d Cir.) (discussing fiduciary duties of majority stockholder/director), cert denied, 349 U.S 952 (1955).

78. See, eg., Jones v. H.F. Ahmanson \& Co., 1 Cal. 3d 93, 108, 460 P.2d 464, 471, 81 Cal. Rptr. 592, 599 (1969) ("Any use to which [the majority shareholders] put the corporation or their power to control the corporation must benefit all shareholders proportionately and must not conflict with the proper conduct of the corporation's business."); David J. Greene \& Co. v. Dunhill Int'l, Inc., 249 A.2d 427, 434 (Del Ch. 1968) (stockholders who determine corporation's policies should face duties and standards comparable to those imposed on directors); see also Note, Jones v. Ahmanson: The Fiduciary Obligations of Majority Shareholders, 70 CoLUM. L. REv. 1079 (1970) (discuss. ing obligations that majority shareholders owe to minority shareholders).

79. See Lewis v. Fuqua, 502 A.2d 962, 972 (Del. Ch. 1985) (diversion of corporate opportunity is "egregious breach of fiduciary duty"); Miller v. Miller, 301 Minn. 207, 219, 222 N.W.2d 71, 78 (1974) (insider may not exploit his position by "appropriating to himself a business opportunity properly belonging to the corporation"). 
ity shares at the minority's expense. ${ }^{80}$ If valuation proceeds under the assumption that the majority has complied with its state-law fiduciary obligations, then any artificial price difference between majority and minority shares, which theoretically could support minority discounting, should not exist. ${ }^{81}$

In discounting minority interests, however, several courts have argued that managerial control itself has value and that lack of it requires a discounted market price. In Perlman v. Permonite Manufacturing Co., for example, a federal district court explained that since the minority shareholders in the case could not force a hiquidation or a declaration of dividends and could not dictate or control corporate policy and operations, their shares were wortli less than a pro rata interest in the corporation. ${ }^{82}$ In Moore v. New Ammest, Inc., the Kansas Court of Appeals stressed the importance of considering control of managerial decisions as an element of stock value in appraisal proceedings. ${ }^{83}$ The economic reality, according to these courts, is that a discount is warranted because minority shareholders lack control..$^{84}$

The real significance of inanagerial control, however, remains unclear. As one commentator has argued:

[No one] has attempted to explain why management power is inherently valuable or why the market would place a premium on its ownership. The usual explanation given really is only a recitation of the various things that voting power entitles a control block owner to do.... [This recitation] fails to explain why participation in management is valuable apart from the fact that it enables one to affect corporate income and asset values. Any other inherent value of management powers is not obvious. One is left with the fecling that the inherent value dẹrives from prestige or other psychic benefits which accompany power. ${ }^{85}$

80. The sale-of-control doctrine, which obligates sellers of controlling interests to investigate a purchaser's financial position and future plans, also limits majority actions. See, eg., Insuranshares Corp. v. Northern Fiscal Corp., 35 F. Supp. 22, $27-28$ (E.D. Pa. 1940) (sellers of controlling interest failed to investigate purcliaser adequately).

81. See Comment, supra note 11, at 146-54 (suggesting that courts' rationales for control premiums and mimority discounts are illogical, inconsistent, or incomplete).

82. 568 F. Supp. 222, 226 (N.D. Ind. 1983), aff'd, 734 F.2d 1283 (7th Cir. 1984).

83. 6 Kan. App. 2d 461, 474-75, 630 P.2d 167, 177 (1981).

84. Some courts that reject a minority discount still accept this reasoning. See, eg. Brown v. Allied Corrugated Box Co., 91 Cal. App. 3d 477, 485-86, 154 Cal. Rptr. 170, 176 (1979) ("[A] minority shareholder who brings an action for the involuntary dissolution of a corporation should not, by virtue of the controlling sliareholder's invocation of the buy-out remedy, receive less than he would have received had the dissolution been allowed to proceed."); Woodward v. Quigley, 257 Iowa 1077, 1087-89, 133 N.W.2d 38, 43-44 (even when value of minority interest is less than average value per slare, minority discount undermines statutory purpose of preventing squeeze-outs), modified on reh'g, 257 Iowa 1104, 136 N.W.2d 280 (1965)

85. Comment, supra note 11 , at $147-48$. 
If control does not account for the difference in value between majority and minority shares, dereliction of fiduciary duties must be the greatest contributor to the gap. ${ }^{86}$ Majority sliareliolders can stray froin their fiduciary obligations because, as currently enforced, sucl obligations do not cominand strict compliance. Since it is both difficult and expensive for minority shareliolders to fight oppression, inajority shareholders will, to some extent, be able to deviate from their fiduciary obligations. ${ }^{87}$ In Delaware, for example, if a majority of minority shareholders vote in favor of a merger and the corporation makes adequate disclosure, the objecting minority shareliolders have the burden of showing that the transaction was unfair to them. ${ }^{88}$ As a result, minority shareliolders will not litigate unless they feel relatively certain that they can ineet this burden of proof and earn a substantial recovery. This difficulty in enforcing minority rights, which stems in part froin a lack of resources for proving such breaches of fiduciary duty, allows majority shareholders to divert corporate benefits to themselves and raise the price of their shares. ${ }^{89}$

Courts can best guard against oppression of minority shareholders by sctting the fair value of their shares high enough to discourage corporations froin attempting to casli out such shareholders at bargain prices. 90 Courts can accomplish this proteetion by awarding a pro rata price in appraisal proceedings. ${ }^{91}$ Since sliareholders invoking the appraisal remedy can usually allege unfairness, ${ }^{22}$ an appraisal price that significantly undervalues minority shares fails to serve its protective purpose. ${ }^{93}$ A corporation will not negotiate in good faith if the most it has to lose is the amount of a discounted appraisal price-especially since it would benefit from any decrease in the value of minority shares. Ironi-

86. But see Andrews, The Stockholder's Right to Equal Opportunity in the Sale of Shares, 78 HARV. L. REV. 505, 526 (1965) (arguing that control insures an investment by allowing implementation of new corporate policies).

87. See L. Solomon, D. Schwartz \& J. Bauman, Corporations: Law and Policy, Materials and Problems 996-97 (2d ed. 1988).

88. Weinberger v. UOP, Inc., 457 A.2d 701, 703 (Del. 1983).

89. Cf. Comment, supra note 11 , at $151-52$ (describing inethods by which majority can engage in self-dealing; noting that impact of self-dealing on value of shares is not sufficiently clear).

90. See 1 F.H. O'Neal \& R. Thompson, supra note 4, at $\$$ 5.31(C), at 193.

91. See Haynsworth, supra note 36 , at 489 (arguing that use of minority discounts could en. courage majority shareholders to "squeeze[] out" minority).

92. See, eg., Weinbenger, 457 A.2d at 703 (alleging that elimination of minority shareholders by cash-out merger was fair); Green v. Santa Fe Indus., 70 N.Y.2d 244, 255, 514 N.E.2d 105, 109, 519 N.Y.S.2d 793, 797 (1987) (alleging unfairly low price in freeze-out merger breaclies majority's fiduciary obhigation).

93. The appraisal reinedy seeks to protect minority shareliolders where a diversion of corporate wealth is likely. See Fischel, supra note 49, at 876. A finding of majority wrongdoing should not, however, be a prerequisite for pro rata valuation. See Columbia Mgmt. Co. v. Wyss, 94 Or. App. 195, -, 765 P.2d 207, 215 (1988) (even if no wrongdoing shown, shareholder should not be penalized for exercising rights he has no choice but to exercise). 
cally, courts that allow minority discounts for the sake of "market reality" merely widen the gap between controlling and noncontrolling prices by limiting the appraisal remedy's ability to deter oppression of minority shareholders. ${ }^{94}$

The Weinberger and Revised Model Business Corporation Act valuation standards, by including rescissory damages in the valuation proceedings, at least partially address concerns about minority oppression..$^{95}$ Appraisals will include damages to compensate for majority misconduct "when appropriate to all the issues of fairness."96 Courts that follow Weinberger in effeet require parties to litigate majority misconduct within appraisal proceedings. ${ }^{97}$ Weinberger does not, however, address the price gap that results from the difficulty of enforcing fiduciary obligations. ${ }^{98}$ Courts can protect against such a gap only by awarding minority shareliolders pro rata value as part of the appraisal reinedy.

\section{Practical Drawbacks of the Minority Discount}

\section{A. The Feasibility of the Minority Discount}

The minority discount not only undermines the appraisal reinedy's protective aim; it is also difficult to apply. Courts that apply a minority discount should do so only to the extent that they use either net asset value or investmeut value in their valuation, since an "autoinatic" discount results from the use of market price. ${ }^{99}$ But courts do not normally

94. See supra note 66 and accompanying text. In the estate and gift tax area, Rev. Rul. 59-60, 1959-1 C.B. 237 , allows courts to devalue minority shares in closely held corporations. In such cases, however, minority shareholders are not coerced into seeking appraisal and thus do not require the statutory protection given to stockholders dissenting from corporate change. In fact, minority shareholders in estate and gift tax cases benefit from discounting. See generally Annotation, Valuation of Closely Held Stock for Federal Estate Tax Purposes Under $\$ 2031$ (b) of Intemal Revenue Code of 1954 (26 USCS \$ 2031(b)), and Implementing Regulations, 22 A.L.R. FED. 31, $72-74$ (1975).

95. See Weinberger, 457 A.2d at 715 (rescissory damages may be appropriate in cases involving fraud, misrepresentation, deliberate waste, or gross and palpable overreaching by majority); REVISED MODEL BusINESS CORP. ACT $\$ \S 13.01(3)$, .02(b) (1984) (in computing fair value of dissenter's shares courts may consider expected appreciation or depreciation due to the anticipated corporate action only where inequity would otherwise result; fair value remedy exclusive unless transaction "unlawful" or "fraudulent"); Herzel \& Colling, supra note 43, at 1531 \& a.19 (allowing rescissory damages deters abuse of minority stockholders' rights and creates incentive for electing appraisal instead of separate lawsuit).

96. Weinberger, 457 A.2d at 714 .

97. Steinberg v. Amplica, Inc., 42 Cal. 3d 1198, 1209-13, 729 P.2d 683, 690-91, 233 Cal. Rptr. 249, 255-57 (1986).

98. See supra notes $86-89$ and accompanying text.

99. See supra note 11 and accompanying text. When determining an appropriate capitalization rate for a corporation, courts further complicate discounting by using price-eamings ratios for corporations "comparable" to the corporation at issue. See Haynsworth, supra note 36, at 477. To the extent that investment value incorporates the market price, that value will, like inarket price, represent a "discounted" value. 
use net asset value absent the likelihood of liquidation and pro rata asset distribution. ${ }^{100}$ Because an appraisal slould give minority sliareholders some value for the possibility of future pro rata distributions, ${ }^{101}$ a court would have to speculate about the likelihood of liquidation to determine the need for, and amount of, any discount. In addition, courts may find it difficult to differentiate among varying sizes of minority holdings, or even to determine if controlling and minority interests exist. Minority shareholders may have a block that, although not controlling, is valued somewhere between the "inarginal" market price and the control price. In addition, im the case of a corporation in which no one sharelolder held a controlling interest, a court could not justify discounting. ${ }^{102}$

Even when a court uses only a corporation's investment value to appraise minority shares, the court must cloose an appropriate minority discount. Courts have not, lowever, agreed on a clear standard for the proper discount figure, and they have applied considerably different discounts. ${ }^{103}$ Discounting thus complicates judicial appraisals, and makes it even more difficult for private parties to anticipate likely appraisal prices. Denying a minority discount, on the other hand, comports with fairness, simplifies the valuation process, and facilitates negotiations between parties.

\section{B. The Minority Discount and Managerial Discretion to Effect Corporate Changes}

The minority discount does not give majority sharelolders an incentive to initiate fundamental corporate changes. Because such changes bring majority shareholders synergistic benefits that are normally unavailable to dissenting sharelolders, ${ }^{104}$ majority shareholders will often

100. See supre note 35 and accompanying text.

101. See supro notes $63-64$ and accompanying text.

102. See Comment, supra note 11 , at 140 n.5.

103. See, e.g. Perlman v. Permonite Mfg. Co., 568 F. Supp. 222, 232 (N.D. Ind. 1983) (finding $15 \%$ discount appropriate although plaintiff's expert advocated discount of up to 90\%), aff'd. 734 F.2d 1283 (7th Cir. 1984); Moore v. New Ammest, Inc., 6 Kan. App. 2d 461, 475, 630 P.2d 167, 177 (1981) (applying 20\% discount). A 1975 survey of tax cases showed that, between 1970 and 1975, discounts ranged from $15 \%$ to $55 \%$, with an average of $34 \%$. See Dant, Courts Increasing Amount of Discount for a Minority Interest in a Business, $43 \mathrm{~J}$. TAX'N 104, 108 (1975).

104. See Brudney \& Chirelstein, supra note 73, at 304-05 (discussing synergistic benefits in parent-subsidiary mergers). Some commentators have argued that majority stockholders should share these benefits, though not necessarily through the appraisal remedy. See, eg., id. at 345-46 (fairness requires that each set of stockholders receive equal return on its contribution to merger); Lone, $A$ Reappraisal of Fair Shares in Controlled Mergers, 126 U. PA. L. REV. 955,987 (1978) (arguing that "fair-share" approach recognizes that directors have competing fiduciary obligations to majority and minority stockholders and must divide assets in an acceptably fair manner); $c f$. Weinberger v. UOP, Inc., 457 A.2d 701, 713 (Del. 1983) (mandating some sharing of synergistic benefits within appraisal process, achieved through consideration of all relevant factors). 
find the price of a minority buyout attractive. ${ }^{105}$ Ordinarily, these synergistic benefits result from economies of scale or more efficient management policies. In some instances, the majority may also gain other benefits from purchasing minority shares. In Dreiseszun y. FLM Industries, for example, majority shareholders acquired minority stock in order to avoid incurring a tax on corporations with more than 100 stockholders. ${ }^{106}$ In any case, a majority shareholder who has purchased minority shares is no longer "subject to the handicaps of a minority stockholder" and thus need not acquire the shares at a discount in order to enjoy the shares' full value. ${ }^{107}$

Even if minority shareholders are entitled to a pro rata appraisal price, the majority's superior resources and bargaining position will minimize the real cost of an appraisal for the majority. The appraisal remedy exists in order to bring the parties together to negotiate a fair price. The majority, however, controls the corporate purse strings and normally sets the terms for the valuation by making an initial offer. Moreover, minority shareholders are unlikely to press for appraisal when the majority makes a good faith offer. The minority will prefer to avoid costly litigation that may yield only minimal real benefit.

\section{The MARKet EXCEPTION}

Almost half of the states provide for a inarket exception to the appraisal remedy. This exception demes an appraisal to minority shareholders in a corporation listed on a national exchange or held by more than a stated number of shareholders. ${ }^{108}$ While not all courts view the market exception as inconsistent with pro rata valuation, ${ }^{109}$ some argue that it theoretically supports the "market realism" rationale that they use to justify the minority discount. These courts rely on the market exception, as well as their use of inarket price in valuing shares, to argue that the appraisal process should aim to discover an actual, active market value or a hypothetical ("sinulated") market value for minority

105. See Fischel, supra note 49, at 886 (arguing that majority shareholders' monopoly over synergistic benefits encourages then to initiate "value-increasing transactions").

106. 577 S.W.2d 902, 908 (Mo. Ct. App. 1979).

107. Woodward v. Quigley, 257 Iowa 1077, 1086, 133 N.W.2d 38, 42, modified on reh'g, 257 Iowa 1104, 136 N.W.2d 280 (1965); see also Columbia Mgmt. Co. v. Wyss, 94 Or. App. 195, -, 765 P.2d 207, 214 (1988) (no discount where corporate purchaser not in minority position following appraisal).

108. See supra note 33 .

109. Iowa, Kentucky, and Oregon, all of which have rejected the minority discount, provide for a market exception. IOWA CODE ANN. § 496 A.77 (West 1962); KY. REv. STAT. § 271A.400(3) (Baldwin 1983); OR. REV. STAT. \$ 60.554(3) (1988). Mississippi, which allows the tninority discount, does not have a market exception. See Miss. CODE ANN. $\S 79-4-13$ (Supp. 1988). 
shares. ${ }^{110}$

These courts rely on hypothetical market value whenever the fair value of shares diverges from their market price. This divergence occurs in two instances. The first and most obvious case is where no active market exists for the shares. In this case, valuation of the shares necessarily requires speculation. A court may know the price at which a small number of shares traded years ago, but that price does not necessarily represent the shares' current market price.111 Second, even when an active market does exist, restricted information may cause the shares' fair value to diverge from the market price:

If the public stock market functioned as a perfect market, where all actors relied upon complete and accurate information, then courts would need to look ouly to the stock market price, and the valuation of dissenters' shares would be greatly simplified. Unfortunately, a perfect market is only a theoretical and abstract ideal, and in the real world the stock market is to varying degrees less than a perfect indicator of the value of a corporate concern. ${ }^{112}$

Thus, if an efficient market exists, the valuation price will be the market price. If no efficient market for the shares exists, courts will apply a hypothetical market standard. ${ }^{113}$

One court has defined the hypothetical market standard as the price "a willing seller would take and a willing buyer would give in a free arm's length transaction in which the parties are informed as to the facts requisite for a rational judgment."114 Under that standard, a court uses all of the valuation elements of the Delaware block method or the Weinberger standard to obtain a pro rata value for minority shares. ${ }^{115}$ Instcad of stopping at this point, however, courts favoring a minority discount then analogize to the hypothetical market. In finding hypothetical market value, these courts consider every factor that could influence market price, including the marketability of the shares and the minority status of the holding in question. ${ }^{116}$ Although these courts accept pro rata value

110. See, e.g., Perlman v. Permanite Mfg. Co., S68 F. Supp. 222, 229 (N.D. Ind. 1983), aff'd, 734 F.2d 1283 (7th Cir. 1984) (statute requiring courts to determine "the value" of dissenters" shares means "fair market value"); see also Brudney \& Chirelstein, supra note 73, at 307 (discussing hypothetical market value in context of parent-subsidiary merger); Seligman, supra note 8, at 837 (argu* ing that courts should determine "fair value" by using hypothetical free market).

111. See supra note 34. Markets are often thin for the securities of closely held corporations.

112. In re Valuation of Common Stock of Libby, McNeill \& Libby, 406 A.2d 54, 60 (Me. 1979).

113. See, eg., id (since solne market distortion always occurs, every valuation proceeding should involve mix of factors).

114. Id. at 61 n.8. A statute may dictate the willing-seller-willing-buyer standard. See, eg., Ohio Rev. Code ANN. \$1701.85(C) (Anderson 1985).

115. Libby, 406 A.2d at 61 n.8.

116. See, e.g., Perlman v. Permonite Mfg. Co., 568 F. Supp. 222, 232 (N.D. Ind. 1983) (considering discount for minority interest, lack of marketability, and lack of diversity in determining mar. 
as a useful tool for determining fair value under the appraisal remedy, they feel bound to recognize market "truths" and discount fair value to mirror the minority/majority price differential. ${ }^{117}$

These courts argue that they must apply a minority discount in order to avoid the discrepancy in valuation that results from the use of different valuation methods: net asset and investment value yield a pro rata appraisal, while market value yields a marginal market appraisal. According to these courts, minority discounting also avoids the imbalance that results when soine dissenters have access to the appraisal reinedy and others are left to the "Wall Street rule" because their shares are in a public company. The arguinent that the market exception clashes with pro rata valuation rests on two unstated assumptions: (1) that legislatures have authorized a market exception solely to force minority shareholders to accept the market's "discounted" prices for their shares, and (2) that individual shares sold on the market reflect a minority discount.

Both of these assumptions are questionable. First, scveral practical considerations would encourage legislatures to rely on the market if the market were active enough to provide an accurate reflection of a corporation's value. In the absence of a perfect market, a range of possible valuation figures and methods exist. Courts may, of course, use one of the cumbersome appraisal calculations to approximate fair value. Some legislatures have believed, however, that an active market could also provide shareloolders with a reasonably fair value for their shares. The market provides nothing more than an accessible approximation of fair value, and requiring shareholders to usc it conserves judicial resources

ket value), aff'd, 734 F.2d 1283 (7th Cir. 1984); Atlantic States Constr., Inc. v. Beavers, $169 \mathrm{Ga}$. App. 584, 589-90, 314 S.E.2d 245, 251 (1984) (despite denying determination of hypothetical market price, court defined "intrinsic worth" to mirror hypothetical market value). Some courts that allow a marketability discount, however, do not allow a minority discount. See, e.g., Ford v. CourierJournal Job Printing Co., 639 S.W.2d 553, 556-57 (Ky. Ct. App. 1982); Raskin v. Walter Karl, Inc., 129 A.D.2d 642, 644, 514 N.Y.S.2d 120, 122 (1987); Blake v. Blake Agency, Inc., 107 A.D.2d 139, 149, 486 N.Y.S.2d 341, 349 (1985); Columbia Mgmt. Co. v. Wyss, 94 Or. App. 195, —, 765 P.2d 207, 213-14 (1988). If a close corporation's shares are not marketable, its worth as a whole will decline harming all of the corporation's shareholders. Because of the perceived disadvantages of lack of control, however, the noumarketability of a close corporation's shares will most likely injure minority shareholders more than it will those with majority interests. Nevertheless, courts applying significant marketability discounts have stated that they are discounting for marketability and not for minority status. See, eg., In re Fleischer, 107 A.D.2d 97, 101, 486 N.Y.S.2d 272, 275 (1985) (dissolution action).

117. See, eg., Perlman, 568 F. Supp. at 231-32; Moore v. New Ammest, Inc., 6 Kan. App. 2d $461,474-75,630$ P.2d 167, 177 (1981). Carried to its logical conclusion, however, this approach no longer favors a minority discount, since an efficient market operating in compliance with state standards of fiduciary conduct would value minority and majority shares equally. See supra notes 91 105 and accompanying text. 
and avoids the hypothesizing of self-serving appraisers. ${ }^{118}$ Just because soine appraisal statutes force shareholders to sell their shares in the inarket in certain circumstances does not inean that the goal of the appraisal process is to duplicate the market or that the market price will always protect minority shareliolders. ${ }^{119}$

Second, by liolding majority sharelıolders accountable for minority oppression, courts will minimize any minority discount or control premium reflected in the market. ${ }^{120}$ Moreover, because the pro rata price derived from a net asset or investment valuation lies between the coutrolling and noncontrolling market prices, the difference betwecn that pro rata price and the minority market price is even smaller than the minority/majority differential.

Viewed in this light, the market exception adds certainty to the appraisal process only when the inarket price approximates fair value. The exception does not support minority discounting as a second-stage adjustment.

\section{CONCLUSION}

The appraisal remedy grants courts broad authority to award dissentimg shareliolders fair value for their stock. In calculating fair value, courts can further the aims of dissenters' rights legislation and best guide private valuation negotiations by rejecting a second-stage minority discount. By rejecting the discount, courts would properly rccognize the appraisal remedy as a quid pro quo for minority shareholders' common law veto power. More importantly, rejecting a minority discount protects the minority shareholders' rightful expectations of receiving pro rata value for their shares. Without the minority discount, the appraisal remedy more effectively safeguards against bad faith and coercion by majority shareliolders. Moreover, because courts cannot fairly and aecurately calculate the minority discount, the discount merely adds confusion to the already difficult valuation process. Finally, the discount is unnecessary to preserve inanagement's ability to initiate fundamental corporate changes. By rejecting the discount, courts would strike an optimum balance between flexibility for inanagement and protection for minority sliareliolders.

Robert B. Heglar

118. Seligman, supra note 8 , at 837-38.

119. See Wyss, 94 Or. App. at - 765 P.2d at 214 (appraisal not designed to produce result equivalent to sale on open market); see Eisenberg, supra note 14, at 82-85 (recourse to market cannot adequately protect minority shareholders).

120. See supra notes $\mathbf{7 7 - 9 0}$ and accompanying text. 